\title{
Viewing Omnibus Law's Policy in a Governance Ethics Perspective through Social Media Twitter
}

\author{
Dedi Kusuma Habibie ${ }^{1}$, Sanny Nofrima ${ }^{2}$, Prawira Yudha Pratama ${ }^{3}$, Herdin Arie Saputra ${ }^{4}$, Danang Kurniawan ${ }^{2}$ \\ ${ }^{1}$ Public Administration, Universitas Riau, Kampus Bina Widya KM. 12, 5, Kota Pekanbaru, Riau 28293, Indonesia \\ ${ }^{2}$ Master of Government Affairs and Administration, Universitas Muhammadiyah Yogyakarta, Jl. Brawijaya, Daerah Istimewa Yogyakarta 55183, Indonesia \\ ${ }^{3}$ Doctoral Political of Science, Universiti Sains Malaysia, 11800 Gelugor, Penang, Malaysia \\ ${ }^{4}$ Universitas Muhammadiyah Semarang, Jl. Kedungmundu No. 18, Kedungmundu, Semarang 50273, Indonesia
}

\begin{tabular}{l}
\hline ARTICLE INFORMATION \\
\hline Received: February 12, 2021 \\
Revised: March 16, 2021 \\
Accepted: April 20, 2021 \\
Available online: April 27, 2021 \\
KEYWORDS \\
\hline
\end{tabular}

Government Ethics, Social Media, Omnibus Law, Hashtag, Twitter

\section{CORRESPONDENCE}

E-mail: dedi.kusuma@lecturer.unri.ac.id

\begin{abstract}
A B S T R A C T
Social media can quickly help people interact with the Government and use technology to turn communication into interactive dialogue. This study looks at Omnibus Law policies from government ethics through social media Twitter hashtag (\#) Omnibus law. The method used in this research is qualitative, then data is collected from the Twitter hashtag using Nvivol2 Plus to analyze the data. This study's results reveal that the Hashtag (\#) Omnibus Law's effectiveness is proven to be efficient in viewing data analysis through information dissemination on Nvivol2 Plus on Twitter to see policies and responses from the public who use the Hashtag ( $\#)$ Omnibus Law.
\end{abstract}

\section{INTRODUCTION}

Omnibus Law is no longer new globally, such as in the United States, Canada, Australia and other Omnibus Law countries. According to (Busroh, 2017) The word Omnibus means to all in Latin, in the Black Law Dictionary Ninth Edition of Briyan A. Garner mentioned Omnibus means to relate, deal with objects or at once, and if in conjunction with the word Law then it can be defined as the Law for all. Juridically, the establishment of Indonesian legislation, the emergence of Omnibus Law with the draft Act of Cipta Kerja, tax Law and the Empowerment Act of Micro Small enterprises that contains 79 laws, 15 chapters and 174 chapters with a target of 11 clusters that will be set in the Omnibus law that is a cluster of simplification of licensing, investment requirements, employment, ease of empowerment and protection of micromedium enterprises, research and innovation support, government administration, sanction, land procurement, investment and government projects, as well as commercial and industrial areas.

The omnibus law policy was discussed on October 20, 2019, in public when the inauguration of Joko Widodo as president for the second period of 2019-2024, in the House of Representatives of the people The Republic of Indonesia in his official speech and on Wednesday, January 22, 2020, and was passed on February 12, 2020, which ratified the four packages of Omnimbus Law from 50 revised legislation entered by the national legislation Program Priority 2020 (Kompas.com, 2020). Regulation in the concept of omnibus Law that makes one new Law to incorporate multiple codes at once. The emergence of the Omnibus Law policy that makes controversial for some parties is a concern for farmers' competitiveness. It opens opportunities for outside investors to be able to enter Indonesia quickly. Besides, Omnibus Law aims to revoke, add, and change some laws at once by making it a document so that it is increasingly evident that the Government will regard omnibus Law as a solution for simplifying various regulations.

Omnibus Law's idea immediately got polemic in the middle of society in the preparation of the revision of the Law of copyright work does not describe the needs of the whole community, this can be seen from various government statements that mention that the review of the Copyright Act is one of the means of simplifying and regulation that aims to provide the ease of investment in Indonesia that gives hope of positive impact The interests of the community must accommodate in the rules that will result in the omnibus law scheme. The establishment of the revised Act shall have the principle of openness and participation. So community involvement should also be an essential variable in the process of streamlining the regulation. Governance ethics in its practice are always faced with problems in the love organization. According to (Tamar et al., 2017), the government ethics is an association of government governance process that concerns the importance of the implementation of duties and responsibilities of complying with various provisions and legislation to carry out a good working relationship. The public policy aims at the values and social practice in the community that means any public policy should not contradict the interests of the city because the orientation of public policy will

Attribution-ShareAlike 4.0 International. Some rights reserved 
return to the community and its environment (Wahyuningsih, 2019).

The omnibus law decision includes policies that do not involve the public in developing such regulation which has been said in Law No. 15 of 2019 on the establishment of legislation. Because it is omnibus Law to be a public conversation, especially on social media, because social media is a new media that according to (Yuliani et al., 2020) operates in the network that has been utilized in the Life of public both economic, social, political, and cultural. Omnibus Law emerged from habits in the standard law system since 1937 (Asshidiqie, 2019). Omnibus Law has been practised in several countries such as Ireland, Canada, and America Union. An example of implementing laws in Ireland has succeeded in reaching 3,225 laws to become just one Law (Rongiyati, 2019). If traced its etymology or the origin of the word, omnibus comes from Latin, which means many. This omnibus Law in the United States is better known as the omnibus bill concept. According to Henry Campbell Black in the Black's Law Dictionary what is meant by the omnibus bill is "In legislative practice, a law is included in a single law of different things that are separate and different, and in particular one that combines several different subjects in one measure in such away. To compel the executive authority to accept terms it disagrees with or defeat the entire ratification (Black, 1968)". The Omnibus Law is a breakthrough to simplify existing regulations in Indonesia. Black (1968) explains that the omnibus law seeks to make the diversity of rules into one Law only. Asshidiqie explained that omnibus Law's practice could be used in three situations, namely laws that will be directly adjusted, laws that will not be directly related, and regulations that will be produced are not related, but in practice intersect (Suradinata, 2019).

The substance of the omnibus law will be cross-sectoral in the field of Law. This is clearly in contrast to the order of rules in a strict and rigid civil law system whose substance is limited to the Law title. The omnibus Law is a format for ordering comprehensive laws with the help of other laws related to the substance regulated by the amended or established Law (Asshidiqie, 2019). With the Omnibus Law Order format, ordering one Law is made by considering all material provisions that are directly or indirectly regulated in various laws at once. This was also emphasized by Mirza Satria Buana, quoting Sulasi Rongiyati, that the omnibus law can be referred to as the 'Sweep Jagat' Law, which can replace several legal norms several laws (Rongiyati, 2019). In the civil law legal system, the concept of omnibus Law has never been heard because, in the civil law legal system, the codification of regulations is prioritized to address overlaps and partialities of existing rules. Thus it can be concluded that codification with omnibus laws is different where codification only collects existing statutory regulations to be made into one book or book.

Meanwhile, the omnibus law seeks to replace existing rules and norms overlap between one Law and another. Codification can only be carried out against laws that have the same norm content in the legal field. The omnibus Law can collect various kinds of regulations related to the omnibus law topic to be made. When viewed from traditional norms, codification efforts will not lead to new legal rules because codification is only limited to collecting existing standard rules. The omnibus Law will later generate new legal rules where the new Law will likely replace, modify, or eliminate the old standard rules.
Social Media comes with different ethics and regulations due to technological devices that are a machine that is online or can arise due to interaction between fellow social media users (Mulawarman \& Nurfitri, 2017). According to (Fitriani, 2017) Social Media as a container to participate, share, exchange information and netted virtually. Looking at the current conditions of social media can be utilized with anyone can be a newsmaker and impact the crowd. Social Media is also a means of communication in interacting from sharing insights between users on a full scale through social networks Facebook, Twitter and Youtube (Hasanah et al., 2015). Social Media is also a reference to news or political information for the present generation, and that information is discussed with the surrounding people before they make political (Krina \& Munawaroh, 2018).

The increased effectiveness of governance performance through social media intermediaries is a government movement and eventually manages to create social media as one of the community's mobilizers (making social movements). While according to, (Doni, 2017) behaviour in the actions of one's use of information technology, the behaviour is the real use of the technology. The study (Syahputra, 2017) said the context of democracy affects people in view on social media. Its specific Twitter is the type of social media that most influence political change by forming public opinion because it has a fence (Hashtag) facilities.

The government has widely adopted twitter to communicate with the public. Service delivery reflects the characteristics of government tweets and demonstrates the nominal significance of the Canadian government's commitment to using Twitter as part of an established and widely recognized e-government strategy (Small, 2012). The media played a mediating role in increasing public credibility in the government's Twitter stream, via tweets from influential government officials. Moreover, citizens' trust in state media becomes a moderator to convey their trust in the government as a whole (Park et al., 2016).

Twitter Analytics for Government Intelligence and Public Participation (TA4GIP) may help classify and assess specific areas in the role and involvement of government officials in social media, such as irregular activities, significant issues under consideration, public opinion on current policy, emotional correlation, and other factors The subject has led to polarization between voters and a lot of others in reaction to certain government announcements (Hubert et al., 2020). Twitter is basically a tool for communication with users and has become a major feature with the enhancements to Twitter features. The core elements of the social permit system: authenticity, reputation and trustworthiness; it can be achieved by using Twitter to include subscribers (Howard, 2020). An increase in Twitter activity has an inverse impact on participation (Stone \& Can, 2020).

Not all accounts are directly operated by department staff and the account managers are aimed at creating a network of "resistance" through science data shares, disinformation corrections and news cycles. They are based on Twitter's reference characteristics to extend this by over 140 characters (Oltmann et al., 2020). The use of Yogyakarta Special Region's Twitter Regional Disaster Management Agency (BPBD) account has effectively disseminated and conforms with the key Regional Disaster Management Agency's (BPBD) duties and 
functions set forth in the regional legal basis. In all areas of government, however, more digitisation is required to make it more interconnected and transmitted in crisis management (Juswil \& Nofrima, 2020). The effectiveness of Twitter's media in detecting major incidents, political actions, civil complaints, and other facts both in space and time (Alomari et al., 2021). The primary force in creating a reputation on Twitter is Senator-driven tweet. In order to promote initiatives that are distinctive in local issues, senators follow a multimedia representation style that prioritises legislation (Russell, 2021).

Unprecedented observations into the dissemination of Twitter's COVID 19, which will help educate government and public health organizations about potential riskings and disaster communication plans in the digital world relevant to the global threat (Wang et al., 2021). Twitter data provide policy-related material, but most of our data is of little significance and has certain difficulties and restrictions in relation to relevant data. We managed to measure the change between 'standard' and 'crisis' times of relevant details (Vydra $\&$ Kantorowicz, 2021). $73.0 \%$ of those views are negative, $18.0 \%$ positive and $9.0 \%$ favorable. This will provide the government with an early warning to see the people react with any proposal. To allow any policy to be better assessed (Permana et al., 2021)

This research will focus on the view of Omnibus Law's policy in governance ethics perspective through social Media Twitter \#OMNIBUSLAW.

\section{METHOD}

This research uses qualitative research methods. The qualitative approach is a scientific research method that is the objective-oriented and reflective method (Gumilang, 2016). The qualitative approach used in this study is a descriptive qualitative method with data using NVIVO 12 Plus data application. With this, the author outlines the flow of research methods in figure 1 .

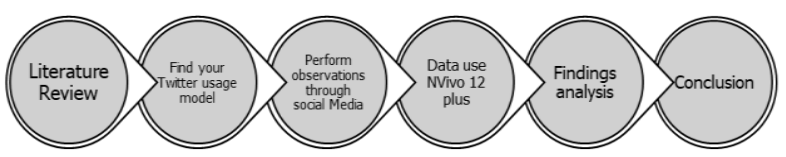

Figure 1. Research Methods

Source: Processed by the author

In this study began conducting review literature to find problems related to research and data that support research. Researchers do data retrieval using Ncapture afterwards indirect use with the help of data processing software Nvivo 12 plus, a software used to perform processing of existing data automatically, then analyze data through data that has been processed using Nvivo 12 Plus. The result later became the analysis of the research continued to be concluded. The data in this research author conducts research using the relevant journals and literature from various sources of literature studies, then social media data obtained by processing social media data on Twitter hashtag Omnibus law utilizing Nvivo 12 Plus.

\section{FINDING AND DISCUSSION \\ The Poliy of Governance Ethics}

Building people's welfare and cultural resilience is a significant development agenda with strategies that should be followed by the settlers or effective policies to realize the lives of people who are justice and prosperous (Alam, 2005). To understand all critical role of ethics in the public sector that contains the value of ethical values in the Government, ethics has the purpose and importance for implementing the State and society as a recipient of service so that openness and accountability in practice (Abas, 2017). Political ethics is one of the efforts that allow social institutions to distribute fundamental rights and obligations and determine the sharing of profit directed towards justice in the formulation of public policies made by the Government to build communities and governments (Funome et al., 2012). The community's resulting policy needs to be known so that the procedure can be carried out well and get community support. The substance of public policy review is then understood by the public in implementing public Policy (Herdiana, 2018). The fact of the policy is the decision making by the aims, principles and rules relating to the strategic thing to lead the organization and the individual that is an implementation for the Life of society (Suwarno, 2016). According to (Surjana, 2018) public policy and performance is a program that involves all stakeholders, namely government, public and private programs aimed at the general plan can fulfil the importance of the procedure itself. Policy as an act proposed by a person, group or Government in a particular sphere provides barriers and opportunities to the administration to overcome or realize a specific goal (Dasril, 2017).

Implementation of government policy is not an entirely smooth research path (Matnuril et al., 2019). Several factors cause inhibiting the implementation of policies, especially conservation area of National Park, namely, conflicts of interest, communication, coordination and support of facilities and infrastructure and regulation. Meanwhile, according to (Kendi, 2018) in his research, the policy's implementation is implementing the political decision. It then becomes visible in the bureaucracy that has the authority to support adequate resources so that the policy is on target.

While according to (Ramdhani, 2017), the implementation of the policy is a stage to implement the policy decision conducted by the Government or community group to achieve the objectives that have been set in the policy decision to influence the outcome of the final policy to be applied. According to (Tomuka, 2013) The Factor that encourages the realization of good governance is the culmination of political management that requires various governmental processes and the process of formulation of public policies to create a transparent, effective and efficient way to improve people's welfare. Transparency of public policy is a principle that guarantees the freedom to obtain information about regulatory governance or government openness in making policy to be known and supervised by Governments and communities (Frisdiantara \& Halim, 2015).

Social welfare is an integral part of the ideals of independence and the economic development plan's estuary. Article 33 of Constitution 1945, which is the article on the economy is in chapter XIV of Constitution 1945 entitled "Social welfare". The community has a position as the subject of 
decision making and benefits in developing tourism, as a sector that has multisectoral in processing and development (Sururi, 2018). The study (Harsin \& Listiani, 2015) found from the 3 (three) aspects of the process of implementing the village funds allocation policy consisting of the organization stage, interpretation stage (interpretation) and the application phase. Public policy is much discussed among the community that the community needs an approach from the Government that is profitable and party to the community's daily Life (Putra et al., 2018).

\section{To The Policy through Social Media Omnibus Law}

New Media provides extensive and flexible use but can also provide chaos. The emergence of new media marks a late period in interactive technology and network communication through the virtual world that will change the community (Gunadi \& Junaidi, 2019). In research (Mahaswari, 2012) says that new media has offered a new way of supporting a social movement in society. Social Media is experiencing a very rapid existence in Indonesia, and being a means of social media information is also a means of mass communication in community activities. Internet utilization has increased in the development of the world such of economic, social and political fields. The twoway WEB 2.0 creates and exchanges users' content in social media that influence how to communicate in the community with the presence of all information access quickly in the know, but through social media can also provide opinions and perceptions of different people. As shown in figure 2 Read Google Trends Graph Data.

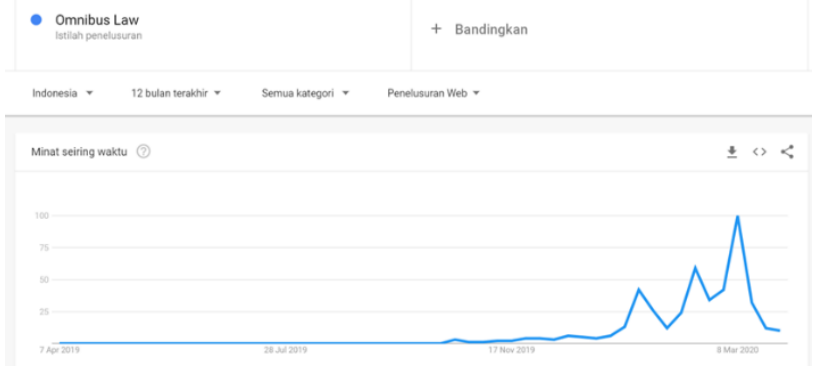

Figure 2. Read Google Trends Graph Data

Source: Processed by researchers using Google Trends

The picture above explains that, the last 12 months of the March 2020 keyword trend of Omnibus Law. Experiencing a hike in March was caused by Omnibus Law to undergo many directions in social media and news through Google. Based on Google Trends charts above starting from the year 2019 increase until March which became the peak omnibus law has many become a conversation in cyberspace not only that omnibus Law is also a stranger in hearing by the people of Indonesia but, through social media or Internet access to find new things, it feels comfortable at the can. Information can search through social media. According to (Wibawanto, 2015) various views appear in many different terms in social media, many terminologies popping up but the word that social media is a container where users can easily share and create messages.

\section{To The Policy through Twitter $\sharp$ OMNIBUSLAW}

Twitter is one of the new media that creates political communication through the dissemination of information and activity intensity through the Hashtag. A hashtag written with a \# symbol is used to detect keywords or topics on Twitter. This functionality is created on Twitter and allows users to follow the issues they are interested in quickly. Indonesia ranks as the 5th largest Twitter user globally, not just that Indonesia is also the Internet user in Indonesia currently reaches 63 million people. From that number, 95 per cent used the Internet to access social net-nets (kominfo.go.id). The selection of Twitter as a tool for information dissemination is already appropriate. According to research, Twitter is indeed the most influential social media in the speed of information dissemination. This is different from Facebook that tends to be done in terms of time. From this figure, we can see that Indonesia makes Internet access in its people's lives, from economic, social and political aspects. Political communication According to (Setiadi, 2016) is communication that voices organizations, Governments and specific groups that use social media for public opinion in developing their ideology. The existence of social Media is also realized by the owner of the account (users) itself. Still, it also serves as a portal to create a virtual friendship network such as audio or video (Hamna, 2017). Social Media is not only a means of information. Yet, it has become a political facility to climb trending in the determination of elections or make social Media for political talks. As shown in figure 3. Twitter By Hashtag Activity Intensities

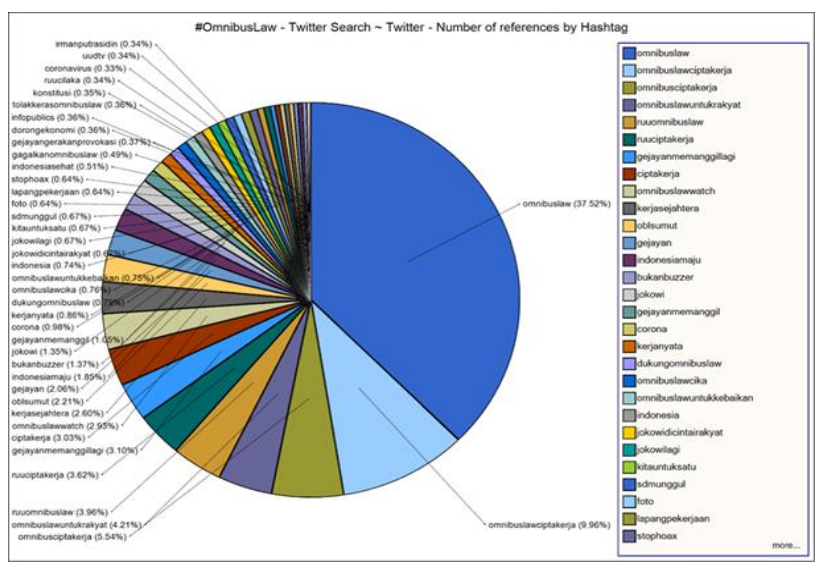

Figure 3. Twitter By Hashtag Activity Intensities Source: Processed by researchers using NVivo 12 Plus (2020)

The above data is taken through Nvivo 12 Plus which explains that the activity in the Twitter hashtag omnibus law starts from the exit of the policy conveyed by President Joko Widodo about omnibus Law will be applied in the regulation of Indonesia has a percentage of $37,52 \%$ because, has occurred in the event of the omnibus law by President Joko Widodo on the inauguration speech on October 20 2019, The discussion of intensive cross-ministry and institutions since November 2019, then the emergence of the manuscript Omnimbus Law was taken before the People's representative Council determines the national legislation Program (Prolegnas) Priorities 2020 and Wednesday, January 22 2020, the House of Representatives confirmed four packages of Omnimbus Law from 50 revised legislation entered national legislative Program Priority 2020. The percentage of increase in because in March has lasted demonstrators attended by students performing a protest movement against the emergence of Omnibus Law, which is considered not meeting the community's needs. So, it's hashtagged the omnibus law to be trending on Twitter. Of the several points in the omnibus law copyright employment that is 
considered detrimental to the workers among others in the elimination of minimum wages, elimination of severance, the inclusion of foreign workers, the absence of social security, loss of sanctions on entrepreneurs offenders as well as the flexibility of employment market and expansion of outsourcing. Impressed by the government ethics in organizing policies that do not involve the community in the creation of the omnibus law which is where the government ethics in its essence to enforce ethics behave, behaved, acted and for every local Government and community organizers to perform the task, function, role, authority and responsibility in the implementation process (Perrara, 2016). As shown in figure 4 Omnibus Law Sentiment on Twitter

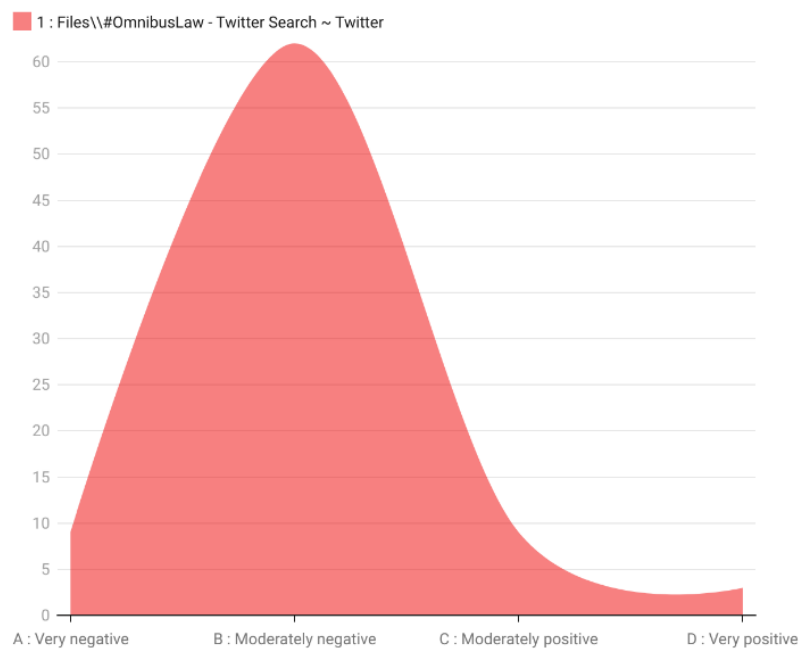

Figure 4. Omnibus Law Sentiment on Twitter Source: Processed by the author

The picture above shows the reaction of Twitter account users in discussing omnibuslaw policies by creating an omnibuslaw hashtag (\#omnibuslaw). This reaction explains that moderately negative sentiment is most dominant with (frequency $=62$ ), followed by very negative and moderately positive with (frequency $=9$ ), and finally with very positive (frequency $=3$ ). It can be concluded that the conversation of Twitter account users on omnibuslaw policies can respond to negative sentiments and respond to protest movements from every element of society.

Judging from the emotional reactions of these Twitter users, this is inseparable from several substantive environments of comprehensive legal policies that are considered detrimental, such as jobs that are considered detrimental to workers, including the elimination of minimum wages, elimination of severance pay, foreign workers, lack of social security, etc. As shown in figure 5 Map Nvivo 12 Plus.

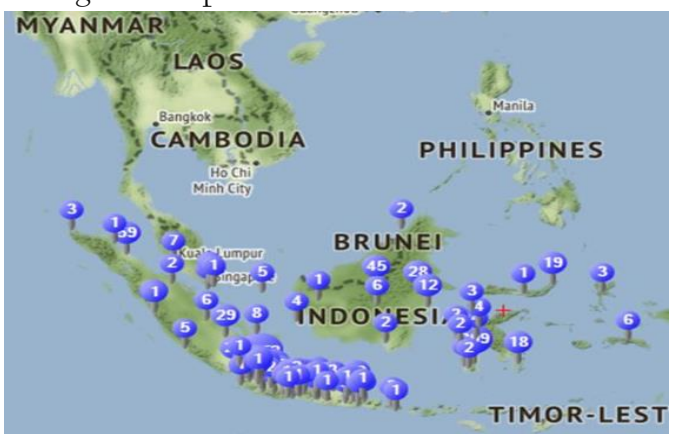

Figure 5. Map Nvivo 12 Plus

Source: Processed by researchers using NVivol2 Plus (2020)
The above Data explained that the use of the hashtag omnibus law has been widespread, this one form of public response to the omnibus law can be seen in the picture above that the help of Hashtag outside spread across Indonesia in the hashtag discussion about the omnibus law there are parties or reject their omnibus law because there is no openness between the Government and the community in the making One form of public rejection of the omnibus law, Yogyakarta students were about to hold a massive demonstrator in Gejayan on March 09, 2020, be thousands of students took to the street to represent the public vote about anxiety related to the omnibus law. One social media that is often in the next generation is information and making social media political communication. In the analysis above, it can be seen that the hashtag Omnibus Law is not only widespread in big cities in Indonesia; However, this policy is also a discussion on social media twitter in various neighboring countries. That way, this omnibuslaw policy has become a concern in various cities and neighboring countries who are always updating Twitter in search of trending information or not, and Twitter is also a space for communication between individuals and other individuals, and groups that already have a Twitter account. As shown in figure 6 Word Similarity Nvivol2 Plus

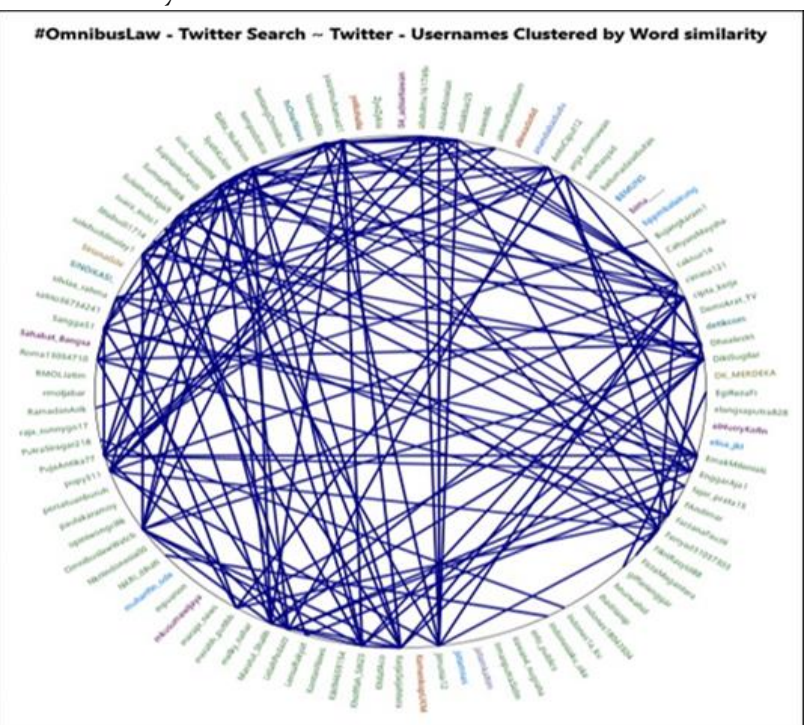

Figure 6. Word Similarity Nvivol2 Plus

Source: Processed by researchers using NVivol2 Plus (2020)

Based on the analysis of the similarity word Nvivo 12 Plus, \#OmnibusLaw is already effective in spreading information through social media. The image above explains that Twitter's user interactions using \#OmnibusLaw are mutually sustainable. The communication of fellow social media users is very rapidly; the emergence of the omnibus law becomes a frequent discussion of the cause; this policy continues to spotlight users using. The Hashtag ( $\#$ ) becomes the relevant keyword or phrase in a Tweet to classify and display the Tweet in Twitter search. Describing words that have hashtags in your message will show other tweets that include that Hashtag. Hashtags can be added anywhere in the Tweet. The dish hashtags that become very popular are often popular topics. The use of Twitter in Indonesia is arguably very observant. It shows significant numbers, even the CEO of Twitter himself stated that Indonesia indeed has a central role in Twitter business trips (Susanto, 2016). 
The above analysis explains that the ethical perspective of governance in the expenditure of the omnibus policy of the Law has not been valid because, before omnibus law policy in the absence of public involvement such as indirectly, the regulation which violates the provisions of law number 15 the year 2019 concerning the establishment of legislation is the implementation of the order of article 22A of the Constitution of the Republic of Indonesia year 1945 stating that "further provisions on the procedures for the establishment of legislation in the form of law". One of the properties in establishing legislation with openness ranging from planning, drafting and discussion to determination. Seeing the effectiveness of social media hashtag, Omnibus Law on Twitter explained that user hashtag Omnibus law domicile of Indonesian people who reject this rule omnibus law because of factual inaccuracy in the regulation and relatively new in Indonesia.

\section{CONCLUSION}

The emergence of an omnibus law policy that made controversial a number of parties became a concern for the competitiveness of farmers. This opens up opportunities for outside investors to enter Indonesia quickly. In addition, the LAW Omnibus aims to revoke, add, and change several laws at once by making it a document so that it becomes increasingly clear that the Government will view the omnibus law as a solution to simplifying various regulations. However, based on the omnibus law hashtag in the form of community refusals who feel that the rule of omnibus law must be a mature policy in the sense that regulations must be in accordance with the needs of the city and involve the community in making appropriate decisions in Law Number 15 of 2019 concerning the formation of statutory regulations. invitation.

The trend of words in the last 12 months using the keyword omnibuslaw has increased in March 2020. This indicates that omnibuslaw is a phrase that is widely discussed by the Indonesian people on Twitter social media. From 2019 to March 2020 the omnibuslaw sentence has also increased. The presence of this omnibuslaw policy also responds to the protest movement of students who are deemed not meeting the needs of society. Several points that can be explained are employment which is considered to be detrimental to workers, including eliminating the minimum wage, eliminating severance pay, the entry of foreign workers, the absence of social security, and others. It seems that the government's ethics in making policies does not involve the wider community. The omnibuslaw trend is also not only spread in big cities in Indonesia, but also to neighboring countries. The interaction of Twitter account users can also spread massively to other Twitter accounts quickly.

\section{ACKNOWLEDGEMENT}

The emergence of the omnibus law policy that makes controversial for some parties is a concern for farmers' competitiveness. It opens opportunities for outside investors to be able to enter Indonesia quickly. Besides, Omnibus LAW aims to revoke, add, and change some laws at once by making it a document so that it is increasingly evident that the Government will regard omnibus Law as a solution for simplifying various regulations. But based on the Repon community in the hashtag omnibus law in the form of rejection of the community who felt that the rule of omnibus Law should be a mature policy in the sense of regulation must comply with the needs of the city and involve the public in the appropriate decision making in Law No. 15 the year 2019 concerning the establishment of legislation.

\section{REFERENCE}

Abas, A. (2017). Urgensi Etika Dalam Tata-Kelola Pemerintahan (Governance). JPSI (Journal of Public Sector Innovations), 1(2), 79. https://doi.org/10.26740/jpsi.vln2.p79-89

Alam, A. S. (2005). Analisis Kebijakan Publik: Konpep Teori Dan Aplikasi. Pustaka Pelajar, 2(9), 9. https://doi.org/10.1017/CBO9781107415324.004

Alomari, E., Katib, I., Albeshri, A., \& Mehmood, R. (2021). Covid-19: Detecting government pandemic measures and public concerns from twitter arabic data using distributed machine learning. International Journal of Environmental Research and Public Health, 18(1), 1-36. https://doi.org/10.3390/ijerphl8010282

Busroh, F. F. (2017). Konseptualisasi Omnibus Law Dalam Menyelesaikan Permasalahan Regulasi Pertanahan. Arena Hukum, 10(2), 227-250. https://doi.org/10.21776/ub.arenahukum.2017.01002.4

Dasril, M. (2017). Evaluasi Dampak Implementasi Kebijakan Publik. Jurnal Dialektika, 66(6), 37-39.

Doni, rohma F. (2017). Perilaku Penggunaan Smartphone Pada Kalangan Remaja. Journal Speed Sentra Penelitian Engineering Dan Edukasi, 9(2), 16-23. https://doi.org/10.1371/journal.pone.0028245

Fitriani, Y. (2017). Analisis Pemanfaatan Berbagai Media Sosial sebagai Sarana Penyebaran Informasi bagi Masyarakat. Paradigma - Jurnal Komputer Dan Informatika, 19(2), 148-152. https://doi.org/10.31294/P.V19I2.2120

Frisdiantara, C., \& Halim, A. (2015). Pengaruh transparansi kebijakan publik terhadap pengetahuan dewan tentang anggaran dengan partisipasi masyarakat sebagai variabel moderasi (Studi pada DPRD periode 2009 - 2014 Kota Malang). Ifma, 20.

Funome, P., Hardiyanto, W., \& Setyawan, D. (2012). Peran Etika Poltik Dalam Perumusan Kebijakan Publik. Jurnal Ilmu Sosial Dan Ilmu Politik Universitas Tribhuwana Tunggadewi, 1(2), 42377.

Gunadi, M. S., \& Junaidi, A. (2019). Keterlibatan Alumni Universitas Tarumanagara dalam Pemilihan Presiden Melalui Media Sosial Instagram. Koneksi, 3(1), 22. https://doi.org/10.24912/kn.v3il.6140

Hamna, D. (2017). Eksistensi Jurnalisme Di Era Media Sosial. Jurnal Jurnalisa, 3(1), 106-120. https://doi.org/10.24252/jurnalisa.v3il.3090

Harsin, A., \& Listiani, E. I. (2015). Kubu Raya Provinsi Kalimantan Barat. 1-11.

Hasanah, N., Nugroho, L. E., Nugroho, E., \& Harati, H. (2015). Analisis Efektivitas Iklan Jejaring Sosial sebagai Media Promosi Menggunakan EPIC Model. 2(2), 99-110.

Herdiana, D. (2018). Sosialisasi Kebijakan Publik: Pengertian dan Konsep Dasar. Jurnal Ilmiah Wawasan Insan Akademik, 1(3), 2-15.

Howard, J. M. (2020). Trains, Twitter and the social licence to operate: An analysis of Twitter use by train operating companies in the United Kingdom. Case Studies on Transport 
Policy,

$8(3)$

812-821.

https://doi.org/10.1016/j.cstp.2020.06.002

Hubert, R. B., Estevez, E., Maguitman, A., \& Janowski, T. (2020). Analyzing and Visualizing Government-Citizen Interactions on Twitter to Support Public Policy-making. Digital Government: Research and Practice, 1(2), 1-20. https://doi.org/10.1145/3360001

Juswil, A. K., \& Nofrima, S. (2020). Government Social Media Existence (Case Study on The Use of Twitter Regional Disaster Management Agency, Province of Yogyakarta Special Region). Journal of Local Government Issues, 3(2), 98110. https://doi.org/10.22219/logos.v3i2.12113

Kendi, I. K. (2018). Implementasi Program Penelusuran Dan Pengembangan Potensi Putra-Putri Papua ( P5 ) Asal Kabupaten Jayapura Provinsi Papua. 16(1)

Kompas.com. (2020). DPR Gelar Rapat Paripurna Sahkan 50 RUU Prolegnas Prioritas Termasuk Omnibus Law.

Krina, L. L., \& Munawaroh, Z. (2018). Partisipasi politik pemilih pemula dalam bingkai jejaring sosial di media sosial. 15, 737-754.

Mahaswari, M. (2012). Jalin Merapi: Penggunaan Media Baru dan Gerakan Sosial Penanggulangan Bencana. Jurnal Komunikasi Indonesia, https://doi.org/10.7454/jki.vli2.7821

Matnuril, Jeddawi, M., \& , Kusworo, B. S. (2019). Implementasi Kebijakan Pengelolaan Kawasan Konservasi Taman Nasional Tesso Nilo Dalam Menjaga Kelestarian Fungsi Hutan Di Kabupaten Pelalawan, Provinsi Riau, Indonesia. 38(2), 1793-1812. https://doi.org/10.11684/j.issn.1000-310X.2019.02.013

Mulawarman, M., \& Nurfitri, A. D. (2017). Perilaku Pengguna Media Sosial beserta Implikasinya Ditinjau dari Perspektif Psikologi Sosial Terapan. Buletin Psikologi, 25(1), 36-44. https://doi.org/10.22146/buletinpsikologi.22759

Oltmann, S. M., Cooper, T. B., \& Proferes, N. (2020). How Twitter's affordances empower dissent and information dissemination: An exploratory study of the rogue and alt government agency Twitter accounts. Government Information 2uarterly, 37(3),

101475 . https://doi.org/10.1016/j.giq.2020.101475

Park, M. J., Kang, D., Rho, J. J., \& Lee, D. H. (2016). Policy Role of Social Media in Developing Public Trust: Twitter communication with government leaders. Public Management Review, 18(9), 1265-1288. https://doi.org/10.1080/14719037.2015.1066418

Permana, F. C., Wicaksono, Z. M., Kurniawan, C., Abdullah, A. S., \& Ruchjana, B. N. (2021). Perception analysis of the Indonesian society on twitter social media on the increase in BPJS kesehatan contribution in the Covid 19 pandemic era. Journal of Physics: Conference Series, 1722(1). https://doi.org/10.1088/1742-6596/1722/1/012022

Perrara, S. (2016). Kinerja Komisi Penegak Etika Pemerintahan Daerah (Kpepd) Dalam Mengimplementasikan Perda No . 1 Tahun 2008 Tentang Etika Pemerintahan. 1.

Putra, I. G. B. V., Bandiyah, \& Noak, P. A. (2018). Gerakan Sosial Politik Meme Pada Media Sosial Instagram Untuk Bali Tolak Reklamasi. E-Journal Politica, 1(1), 1-12.

Ramdhani, A., \& Ramdhani, M. A. (2017). Konsep Umum Pelaksanaan Kebijakan Publik. Jurnal Publik, 1-12. https://doi.org/10.1109/ICMENS.2005.96

Russell, A. (2021). Senate Representation on Twitter: National
Policy Reputations for Constituent Communication. Social Science Quarterly, 102(1), 301-323. https://doi.org/10.11l1/ssqu.12904

Setiadi, A. (2016). Pemanfaatan media sosial untuk efektifitas komunikasi. Jurnal Humaniora, 16(2), 1-7.

Small, T. A. (2012). E-Government in the age of social media: An analysis of the canadian government's use of twitter. Policy and Internet, 4(3-4), 91-11l. https://doi.org/10.1002/poi3.12

Stone, J. A., \& Can, S. H. (2020). Linguistic analysis of municipal twitter feeds: Factors influencing frequency and engagement. Government Information Quarterly, 37(4). https://doi.org/10.1016/j.giq.2020.101468

Surjana, O. (2018). Implementasi Kebijakan Publik Dalam Pembangunan Ruang Publik Pantai Losari Makassar. Jurnal Rekayasa Hijau, $\quad$ l(1), 53-6l. https://doi.org/10.26760/jrh.vlil.1337

Sururi, A. (2018). Inovasi Kebijakan Partisipasi Publik dalam Pengelolaan dan. Jurnal Administrative Reform, 110-121.

Susanto, E. H. (2016). Media Sosial Sebagai Pendukung Jaringan. Aspikom, 1, 379-398.

Suwarno. (2016). Pendekatan Kebijakan Publik dalam Politik Pendidikan Islam. 1(1), 62-72.

Syahputra, I. (2017). Demokrasi Virtual Dan Perang Siber Di Media Sosial: Perspektif Netizen Indonesia. Jurnal ASPIKOM, 3(3), 457. https://doi.org/10.24329/aspikom.v3i3.141

Tamar, M. A., Pangemanan, S., \& Tompodung, J. (2017). Etika Pemerintahan Dalam Meningkatkan Kinerja Aparatur Sipil Negara (Studi di Kantor Kecamatan Siau Barat Selatan Kabupaten Sitaro). 2.

Tomuka, S. (2013). Penerapan Prinsip-Prinsip Good Governance Dalam Pelayanan Publik Di Kecamatan Girian Kota Bitung (Studi Tentang Pelayanan Akte Jual Beli). Jurnal Politico, 1(3), 1-15.

Vydra, S., \& Kantorowicz, J. (2021). Tracing Policy-relevant Information in Social Media: The Case of Twitter before and during the COVID-19 Crisis. Statistics, Politics and Policy, 0(0). https://doi.org/10.1515/spp-2020-0013

Wahyuningsih, C. D. (2019). Mimbar administrasi. 15(29), 14-30.

Wang, Y., Hao, H., \& Platt, L. S. (2021). Examining risk and crisis communications of government agencies and stakeholders during early-stages of COVID-19 on Twitter. Computers in Human Behavior, 114(June 2020), 106568. https://doi.org/10.1016/j.chb.2020.106568

Wibawanto, S. (2015). Kemampuan Media Sosial Menghasilkan Minat Berkunjung Pada Destinasi Baru Di Kebumen. 53(9), 1689-1699. https://doi.org/10.1017/CBO9781107415324.004

Yuliani, F., Adriadi, R., \& Safitra, L. (2020). Media Baru Dalam Pelayanan Publik ( Sosial Media dalam Pelayanan Publik oleh OMBUDSMAN RI Bengkulu). 4(2), 149-157. 